ПСИХОЛОГІЧНІ АСПЕКТИ СОЦАЛІЗАЦІЇ ОСОБИСТОСТІ

\title{
PSYCHOLOGICAL ASPECTS OF PERSONALITY SOCIALIZATION
}

УДК 372:37.035

DOI https://doi.org/10.32843/2663-

5208.2020.12-1.35

\section{Рогальська-яблонська І.П.}

д.пед.н., профресор, завідувач кафредри соціальної роботи

Миколаївський національний

університет імені В.О. Сухомлинського

Султанова Н.В.

д.пед.н., професор кафедри соціальної роботи

Миколаївський національний

університет імені В.О. Сухомлинського Рогальська Н.В.

к.пед.н., профресор, професор кафредри дошкільної освіти

Миколаївський національний

університет імені В.О. Сухомлинського
У статті розкрито розуміння сутності соціалізації особистості з позицій психологічної науки як процесу становлення індивіда як суб'єкта соціальних відносин, що відбувається у процесі його залучення до соціальної дійсності; цей процес має складну структуру, розгортається в конкретних умовах життєдіяльності людини та зумовлюється багатьма фракторами. Наголошується, що процес соціалізації відбувається у конкретному середовищі, тобто у срері соціалізації, під якою у психології розуміють середовище дії, в якому відбувається процес розширення та примноження соціальних зв'язків індивіда із зовнішнім світом, становлення його як особистості. Охарактеризовано основні ссрери, в яких розгортається цей процес, діяльність, спілкування та самосвідомість. Підкреслено, що саме в діяльності людина виражає себе як суспільний індивід, проявляє особистісні смисли, виявляє самостійність ініціативу, творчість та профресіоналізм, засвоює нові види активності. Отже, діяльність являє собою динамічний процес, у ході якого розвивається власне особистість. Акцентовано, що з позицій психологічної науки спілкування трактується як специфрічна фрорма діяльності $і$ як самостійний процес взаємодії, необхідний для реалізації інших видів діяльності особистості. Водночас саме спілкування на різних етапах життєвого шляху стає основним каналом соціалізації особистості. Сфрера самосвідомості - третя ссрера соціалізації - передбачає становлення «Я-концепції» індивіда як динамічної системи уявлень людини про себе, установок, спрямованих на себе. До неї входять: образ «Я» - усвідомлення особистістю власних срізичних, інтелектуальних та інших якостей; самооцінка, потенційна поведінкова реакція, тобто ті конкретні дії, які можуть бути викликані образом «Я» та самооцінкою. Наголошується, що таке зосередження уваги на особистісному аспекті в процесі соціалізації, на активній позиції особистості в цьому процесі є значущим у розробці проблем соціалізації, що вивчається педагогікою, яка завжди використовувала і синтезувала кращі наукові здобутки психологічної науки.

Ключові слова: соціалізація, соціальне становлення, особистість, діяльність, спілкування, самосвідомість, соціальна взаємодія.
The article is dedicated to the investigation of the essence of personality socialization from the psychological approach as a process of becoming an individual as a subject of social relations, which occurs in the process of its involvement in social reality; this process has a complex structure, unfolds in specific conditions of human activity and is caused by many factors. The author emphasized that the process of socialization takes place in a specific environment, that is, in the field of socialization, which in psychology is understood as an environment in which the process of expansion and multiplication of the individual's social connection with the outside world, forming a personality as an individual. The main areas in which this process is involved are characterized by: activity, communication and self-awareness. The activity that a person expresses as a social individual manifests personal meanings, shows independence, initiative, creativity and professionalism, learns new kinds of activity. Thus, activity is a dynamic process in which one develops one's self. The authors pointed out, that from the standpoint of psychological science communication is treated as a specific form of activity and as an independent process of interaction necessary for the implementation of other activities of the individual. At the same time, communication at different stages of the life path becomes the main channel of socialization of the individual.

The sphere of self-awareness - the third sphere of socialization - involves the formation of the "I-concept" of the individual as a dynamic system of ideas of man about himself, attitudes aimed at himself. It includes: the image of "l" - awareness of the individual's physical, intellectual and other qualities; self-esteem, a potential behavioural response, that is, those specific actions that can be caused by the self and self-esteem. The author summarised, that such an emphasis on the personal aspect in the process of socialization, on the active position of the individual in this process is significant in the development of problems of socialization, studied by pedagogy, which has always used and synthesized the best scientific achievements of psychological science.

Key words: socialization, social formation, personality, activity, communication, self-awareness, social interaction.
Постановка проблеми. У контексті реалізації теоретико-методичного дослідження у сфері соціалізації особистості перед дослідником неминуче постає питання про міждисциплінарні підходи до цієї проблеми. Тому найповнішу і найбільш об'єктивну характеристику соціалізації можна отримати лише внаслідок міждисциплінарного її дослідження, що потребує реалізації таких методологічних принципів: соціальної детермінації (соціально-економічний рівень розвитку суспільства визначає особливості існування мікрооточення і позначається на процесі соціалізації); самодетермінації (у процесі соціалізації особистості акцентується увага на активності останньої щодо перетворення матеріальних і духовних цінностей); діяльнісного опосередкування (наявний неперервний цілісний процес засвоєння особистістю об'єктивної дійсності та набуття соціального досвіду завдяки включенню в діяльність); двобічності процесу соціалізації (взаємозумовленості процесу 
входження особистості у систему суспільних відносин і водночас відтворення цих відносин у системі сімейних, товариських, навчальних, виробничих та інших зв'язків).

Виокремлення теорії соціалізації як самостійної галузі дослідження відбулося у середині XX століття і було підготовлене науковими доробками філософів, соціологів, психологів, етнографів, які по-різному розглядали питання становлення людини як компетентного члена суспільства.

Аналіз останніх досліджень і публікацій. Науковцями розроблено сучасні вітчизняні та зарубіжні концепції соціалізації особистості (Н. Голованова, Н. Заверико, І. Звєрєва, Н. Лавриченко, Г. Лактіонова, А. Мудрик, С. Савченко, С. Харченко); розкрито соціально-психологічні аспекти соціалізації з урахуванням вікових особливостей (В. Абраменкова, К. Альбуханова-Славська, І. Бех, Л. Божович, Л. Виготський, Д. Ельконін, І. Кон, О. Кононко, В. Кудрявцев, О. Лєонтьєв, В. Мухіна, А. Петровський, Т. Рєпіна, Д. Фельдштейн). Соціально-педагогічні засади проблеми з урахуванням нової соціокультурної ситуації характеризуються у дослідженнях Т. Алєксєєнко, О. Безпалько, В. Болгаріної, Т. Василькової, Ю. Василькової, М. Галагузової, Я. Гілінського, І. Звєрєвої, А. Капської, Л. Коваль, В. Курила, Л. Міщик, Л. Новікової, А. Рижанової, С. Хлєбік, Л. Штефан. Вивчення процесу соціалізації у межах різних наукових галузей зумовлене глибиною їі об'єктивного змісту і багатством структурно-функціональних взаємозв'язків у суспільному житті. Підходи психолого-педагогічної науки до соціалізації особистості розкривають змістову конкретику цього процесу, обґрунтовують механізми, пов'язані з умовами соціалізації (середовище, простір) та позицією, яку займає особистість у цьому процесі (активність-пасивність).

Постановка завдання. У своїй статті ми намагалися проаналізувати підходи психологічної науки до розуміння сутності соціалізації особистості як процесу становлення індивіда суб'єктом соціальних відносин, що відбувається під час його залучення до соціальної дійсності, має складну структуру, розгортається в конкретних умовах життєдіяльності, та охарактеризувати сфери, в яких розгортається цей процес.

Виклад основного матеріалу. Соціалізація у колі понять соціальної психології посідала досить важливе місце, виділяючи проблему соціалізації як явище, достойне аналізу з позиції марксистської методології, прагнучи вивчати феномен людини, показати відмінність категорій «людина», «особистість», «індивідуальність». Масштабна теоретична дискусія стосовно співвідношення вищезазначених понять, що тривала у радянській філо- софсько-соціологічній та психологічній думці впродовж 1960-1970-х років, зрештою запропонувала чітке розмежування цих понять. Тут доречно процитувати слова В. Ядова: «Якщо вітчизняні науки, предметом дослідження яких є людина, аналізують її якості як біологічного і нерідко біосоціального організму, то особистість, як соціальна якість людини, є предметом дослідження соціальних наук: філософії, соціології і психології» [8, с. 73]. Стосовно особистості соціальну психологію цікавило «конкретно-історичне дослідження особливостей психічних якостей і внутрішньої структури особистості як суб'єкта соціальних відносин, що розглядається у певних соціально-конкретних обставинах» [8, с. 75].

Отже, особливо значущим є те, що у вітчизняній соціальній психології сформувався важливий для концепції соціалізації фундаментальний постулат про особистість як «суб'єкт соціальних взаємин», «суб'єкт індивідуальної життєдіяльності». Такий загальнометодологічний підхід до проблеми особистості з точки зору принципу життєдіяльності був розроблений К. Абульхановою-Славською і засновувався на теоретичних положеннях С. Рубінштейна про людину як «суб'єкт життя». Науковець вважає, що «уявлення про соціальну детермінацію як зовнішню», поширене у психології, $€$ неправомірним. Вона стверджує, що всі «основні параметри індивідуальної життєдіяльності істотно визначені типом суспільних відносин, усі механізми і способи включення індивіда в суспільство, його зв'язки з іншими людьми, його потреби і спонуки суспільно зумовлені» [1, с. 112]. Особисте життя людини може бути відчуженим від неї або, навпаки, виступати її суб'єктом, це залежить від характеру суспільних відносин. Поняття «суб'єкт індивідуальної життєдіяльності» уже містить суспільну зумовленість: воно перш за все характеризує те, як суб'єкт здійснює дію, як усвідомлює світ залежно від його соціальної позиції, від соціальних визначень його суспільної сутності. Тому через поняття суб'єкта передається і міра його активності, і спрямованість, і соціальна сутність свідомості, дій, стосунків» [1, с. 114]. Отже, на думку К. Абульханової-Славської, психологія підійшла до розробки своєрідної «психологічної теорії відносності»: людина сприймає не стільки те, що $є$ у навколишньому світі, скільки те, що саме для неї є актуальним і значущим. Тому для 60-70-х років характерними є постановка та глибока розробка проблеми особистості, концентрація психологічної науки довкола неї. Серед робіт, присвячених зазначеній проблемі, можна виділити праці С. Рубінштейна «Людина і світ», Б. Ананьєва «Людина як предмет пізнання», О. Леонтьєва «Діяльність. Свідомість. Особистість». Оригінальні концепційні 
підходи до трактування поняття «особистість» були розвинуті К. Абульхановою-Славською, Л. Божович, В. Ядовим, П. Якобсон та ін.

Варто зауважити, що вітчизняна соціальна психологія уже у 70-х роках XX століття досить упевнено намагалася пояснити не тільки сутність процесу соціалізації, певні характеристики цього процесу, тобто докладно тлумачити процес соціалізації, але і з'ясовувала її механізми переведення суб'єкта у міжособистісні та міжгрупові соціальні стосунки людей. Так, у Б. Паригіна знаходимо досить точне, хоча і зашироке визначення соціалізації, яку він тлумачив як «багатогранний процес олюднення людини, який містить і біологічні передумови, і саме входження індивіда в соціальне середовище й передбачає соціальне пізнання, соціальне спілкування, оволодіння навичками практичної діяльності, містить предметний світ і всю сукупність соціальних функцій, ролей, норм, прав і обов'язків і т. ін., активну перебудову навколишнього (природного й соціального) світу, зміну і якісне перетворення самої людини, її всебічний і гармонійний розвиток» [5, с. 165].

Досліджуючи процес соціалізації, Б. Ананьєв відносить її «до всіх процесів формування людини як особистості, її соціального становлення, включення особистості в різні системи соціальних взаємин, інститутів та організацій, засвоєння людиною знань, норм поведінки тощо, які склалися історично» [5, с. 144]. Він виділяє певні характеристики цього процесу: першою є стадійний характер цього процесу, який «часто збігається 3 віковими періодами і основними моментами життєвого шляху людини у суспільстві... » [5, с. 145]. Другою важливою характеристикою соціалізації $€$ єдність стадій з її механізмами, «засобами яких здійснюється низка безперервних перетворень індивіда на особистість» [6, с. 148]. Велике значення також мають такі сторони проблеми соціалізації, «як її ефекти, психологічні явища», серед яких особливе місце належить установкам, мотивації діяльності, включаючи ціннісні орієнтації та інтереси, характер, а також процеси інтеріоризації та екстеріоризації.

На залежності ефективності процесу соціалізації від «соціального середовища, від соціально-економічного ладу, від культури, тобто від багатьох власне соціальних характеристик його оточення», наголошував В. Ядов [8, с. 71]. У цьому процесі особистість піддається впливам з боку суспільства на мікро- та макрорівнях. 3 іншого погляду, особистість $€$ не тільки об'єктом тих чи інших впливів з боку соціального середовища, але й суб'єктом діяльності. У цій позиції суб'єкта діяльності особистість повсякденно та повсякчасно розширює свої безпосередні та опосередковані зв'язки, певним чином впливаючи на інших людей, спілку- ючись із ними в різних ситуаціях, співвідносить себе із соціальним довкіллям. У широкому значенні суб'єкт діяльності є її джерелом, її рухомою силою.

Соціалізація особистості як процес залучення її до соціальної дійсності має складну структуру, розгортається в конкретних умовах її життєдіяльності і зумовлюється багатьма факторами. Цей процес охоплює всі аспекти залучення особистості до культури, навчання і виховання, за допомогою яких вона набуває соціальності, спроможності брати участь у соціальному житті. Процес соціалізації відбувається у конкретному середовищі, тобто у сфері соціалізації, під якою у психології розуміють середовище дії, в якому відбувається процес розширення та примноження соціальних зв'язків індивіда із зовнішнім світом, становлення його як особистості. Основними сферами, в яких розгортається цей процес, $€$ діяльність, спілкування та самосвідомість. Першою сферою, яка потребує уточнення у контексті цього процесу, є діяльність. Власне саме в діяльності людина виражає себе як суспільний індивід, проявляє особистісні смисли, виявляє самостійність, ініціативу, творчість та професіоналізм, засвоює нові види активності. Отже, діяльність являє собою динамічний процес, у ході якого розвивається власне особистість.

Засади діяльнісного розуміння процесів психічного розвитку особистості були закладені у 20-30-х рр. XX століття у працях Л. Виготського, О. Леонтьєва, С. Рубінштейна. Важливим з точки зору психологів (В. Давидов, Д. Ельконін, О. Леонтьєв та ін.) $€$ розгляд основних видів діяльності крізь призму генетичного принципу розвитку особистості: від гри дитини у період дошкільного дитинства через навчальну діяльність дітей шкільного віку до трудової діяльності дорослої людини - таким $є$ магістральний шлях розвитку особистості у сучасних соціокультурних умовах. Водночас кожна стадія психічного розвитку характеризується певною системою стосунків між особистістю і соціальною дійсністю, певним провідним різновидом діяльності. Тому тут важливо акцентувати увагу ще на двох важливих поняттях - соціальній ситуації розвитку і психологічних новоутвореннях особистості. На переконання Ю. Швалба, теоретичним підґрунтям подальшого розвитку діяльнісного підходу може стати концепція ґенези особистості С. Максименка [4]. Методологія моделювання ґенези особистості як суб'єкта соціальних відносин, як стверджує Ю. Швалб, утверджує провідним принципом розвитку «принцип ускладнення простого висхідного цілого шляхом диференціації його структурно-функціональних елементів, що призводить до набуття нової якості всієї сис- 
теми» [7, с. 11]. 3 точки зору теорії соціалізації таким висхідним цілим учений уважає «соціально зумовлене ставлення до новонародженої дитини як до абсолютної цінності, а сама дитина включається у таку систему відносин, яка характеризується її абсолютним прийняттям. Проте таке абсолютне прийняття дитини притаманно тільки для віку немовля, а надалі соціальні відносини і міжособові стосунки диференціюються й інтегруються у психологічну структуру особистості як її соціальні здатності. Це ускладнення має закономірний і нормативний характер, що й утворює соціокультурний зміст соціалізації індивіда» [7, с. 11]. Погоджуємося з думкою вченого, що цей підхід дає змогу розглядати соціалізацію індивіда як процес набуття здатності до самостійної побудови і відтворення систем соціальних зв'язків і відносин. Іншими словами, у процесі соціалізації індивід поступово стає суб'єктом різних відносин, а якість цих відносин буде характеризувати його особистість [7, c. 11].

Другою сферою, яка вимагає звертання у зазначеному контексті, є сфера спілкування. 3 позицій психологічної науки спілкування трактується як специфічна форма діяльності і як самостійний процес взаємодії, необхідний для реалізації інших видів діяльності особистості. Водночас саме спілкування на різнихетапах життєвого шляху стає основним каналом соціалізації особистості. Спілкування визначається як найважливіша соціальна потреба, без реалізації якої уповільнюється, а іноді і зовсім припиняється формування особистості. Соціально-психологічний підхід до становлення особистості в соціумі ґрунтується на розумінні комунікативного життя індивіда. Соціалізація особистості поза комунікацією, без співпраці й діалогу, без взаємодії та сприйняття людьми один одного не можлива. Йдеться про широкий діапазон комунікативних знань, умінь і навичок, про соціально-психологічну компетентність та комунікабельність, якими має бути наділений індивід і які є необхідними атрибутами діяльності. Отже, завдяки спілкуванню відбувається поглиблене розуміння себе та інших учасників комунікативного процесу, збагачення змісту взаємодії та сприйняття людьми одне одного.

Сфера самосвідомості - третя сфера соціалізації - передбачає становлення «Я-концепції» індивіда як динамічної системи уявлень людини про себе, установок, спрямованих на себе. До неї входять: образ «Я» - усвідомлення особистістю власних фізичних, інтелектуальних та інших якостей; самооцінка, потенційна поведінкова реакція, тобто ті конкретні дії, які можуть бути викликані образом «Я» та самооцінкою [2, с. 16]. «Я-концепція» виконує потрійну функцію: вона сприяє досягненню внутрішньої узгодженості особистості; визначає характер і особливості інтерпретації набутого досвіду; слугує джерелом очікування стосовно особистісної поведінки і самого себе. Позитивна «Я-концепція» визначається трьома факторами: повною впевненістю в імпонуванні іншим людям, упевненістю у здатності до того чи іншого виду діяльності та почуттям власної значущості [2, с. 32]. Особистість засвоює соціальний досвід, здійснюючи вибір лінії поведінки, зіставляючи зовнішнє та внутрішне, суб'єктивне та об'єктивне. Вирішальним фактором у цьому процесі $є$ момент, коли збігаються чи не збігаються зовнішнє та внутрішне, суб'єктивне та об'єктивне.

Важливе місце у розробці вітчизняної соціально-психологічної концепції соціалізації посідають праці І. Кона. Його погляди на проблему соціалізації з позицій і соціології, і соціальної психології, і етнографії $€$ значним науковим доробком сучасного наукового пізнання. Багатозначний термін «соціалізація» тлумачиться вченим як «сукупність всіх соціальних процесів, завдяки яким індивід засвоює і відтворює певну систему знань, норм, цінностей, що дає змогу йому функціонувати як повноправному члену суспільства. Соціалізація включає в себе не тільки усвідомлені, контрольовані, цілеспрямовані впливи (виховання в широкому значенні слова), але й стихійні, спонтанні процеси, що так чи інакше впливають на формування особистості» [3, с. 21]. Обґрунтовуючи взаємозв'язок та взаємозумовленість процесів розвитку, соціалізації, виховання, освіти, він наполягав на автономізації процесу соціалізації, значною мірою акцентуючи увагу на тому, що з розвитком суспільства, в міру зростання його індустріалізації й урбанізації не лише зростає кількість інститутів і агентів соціалізації, але й збільшується міра відособлення окремих аспектів і функцій соціалізації. І. Кон критикує характерну для консервативних, традиційних систем установку на виховання в дітях слухняності за рахунок придушення їхньої ініціативи та самостійності. Він підкреслює, що така настанова, як правило, обґрунтовується інтересами самої дитини: «щоб вона не наробила помилок, не вдарилася», натомість реальним «спонукальним мотивом батьків і вихователів часто бувають власні зручності: хороша дитина - та, яка спричиняє мінімум неспокою» [3, с. 156]. Отже, «системність» та «комплексність» виховання, бажання організувати авторитарну виховну систему, яка б вибудовувала всі сторони життя дітей - це характерні риси теорії конформності, за якої відбувається недооцінка власної активності дитини, варіабельності її поведінки на всіх вікових етапах. І. Кон акцентує увагу на тому, що «у процесі соціалізації індивіди не просто адаптуються до середовища і засвоюють наявні в ній соціальні ролі та ідентичності, але й навчаються 
«встановлювати, підтримувати і змінювати такі ідентичності», перетворюючи тим самим самих себе і навколишній світ» [3, с. 152]. Таке зосередження уваги на особистісному аспекті в процесі соціалізації, на активній позиції особистості в цьому процесі є значущим у розробці проблем соціалізації, що вивчається педагогікою, яка завжди використовувала і синтезувала кращі наукові здобутки психологічної науки.

Висновки. Проведений аналіз досліджень процесу соціалізації дав змогу зафіксувати розмаїття трактувань і розуміння самого феномена соціалізація та різні підходи до осмислення закономірностей, механізмів, результатів цього процесу. Водночас соціалізація визначає головні засади сутності процесу, у ході якого індивід стає особистістю, компетентним членом суспільства. У різноманітних дослідженнях проблема соціалізації зумовлюється змінами у суспільстві, його культурних нормах, цінностях і пріоритетах. Можемо сказати, що ця дефініція характеризується мобільністю і залежить від здатності особистості реалізуватися у нових умовах. Процес соціалізації уможливлює існування суспільства за рахунок передачі його культури від покоління до покоління, що визначає роль соціалізації в розвитку не лише окремої особистості, але й суспільства загалом. Отже, соціалізація особистості передбачає активні зв'язки із соціумом, що створює тенденції для соціальної взаємодії та активної творчої діяльності людини, розвитку її соціальної активності, в якій виражається та реалізується рівень її соціальності, глибина та повнота соціальних взаємин.

\section{ЛІТЕРАТУРА:}

1. Абульханова-Славская К.А. Активность и сознание личности как субъекта деятельности. Психология личности в социалистическом обществе. Активность и развитие личности. Москва : Наука, 1977. C. $110-134$.

2. Бернс Р. Развитие Я-концепции и воспитание. Москва : Прогресс, 1986. 260 с.

3. Кон И.С. Социология личности. Москва : Политиздат, 1967. 383 с.

4. Максименко С.Д. Генезис существования личности. Киев : Изд-во ООО «КММ», 2006. 240 с

5. Парыгин Б.Д. Основы социально-психологической теории. Москва: Мысль, 1971. 351 с.

6. Человек и общество. Проблемы социализации индивида: Сб. статей / Под общ. ред. Б.Г. Ананьева. Ленинград : Изд-во Ленингр. ун-та, 1971. 199 с.

7. Швалб Ю.М. Психологічні моделі соціалізації особистості. Актуальні проблеми психології. Том 7, № 38. 2015. С. 503-517.

8. Ядов В.А. Личность как предмет изучения. Социальная психология в трудах отечественных психологов / Сост. и общая редакция А.Л. Свенцицкого. Санкт-Петербург : Питер, 2000. С. 70-76. 